\title{
Comparative Anatomy of Citrus and Cold-Hardiness ${ }^{2}$
}

\author{
Gery C. Salarar
}

INTRODECTOX

Cold-tolemene is one of the important properties songht in the selection of citus hybrids and infolutions. It may be a deciding farfor when com-

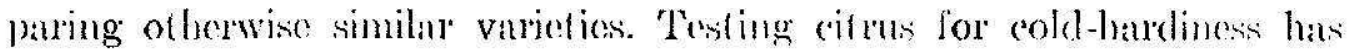
been rlone by axposing the phands to cold, sither maturally or through the nse of frecking fests. The plants maty or may nof have been presonditioned belore the test, although they usmally are, in an allemut lo dupliente the rold days of autumn before winter freeping.

The recognized cold-tolerance of the botter known virieties has been the result of numerous and repeated observations throughout the yenrs. The condition of the plants before a leeying test nuty definitely determine the results obtained. It has been found that the behavion of a rertain varefy may be quite misleading from a given lest. Thus, plants oul of the greenhouse or the field, grown under high temperatures, may be more colel-lolexant. than cold-preconditioned phants $(6,28)$."

Auything which curtails growth to the point of induring shoot, loot, and rimbial dormancy, tends to produce eld-toleranec. Such treatment should not have caused a great increase in resplimtion or in the brealidown of claborated foods in the tissues of the plant, but should have permilted their acemulation and the development of the physiologieal conditions assorialed with cold-hadening. The difliculty in ardificially obtaining such a state before conducting a freeging test is probably one of the causes of contradictory results with the same variety.

'The detection of physical trats which do not depend upon a given physiologieal balanec, and which may be consistently assoriated with roldfolerance, would simplity the sepunation of hatrdy and conder varieties.

\section{REVIEW OF LITERATURR:}

The correlation of cold-hardiness with physical trats has not been very suceessul. Aecording to Levifl (1/), the reported comelations of vadious traits with cold-hardiness offen inchate a number of exceptions, or have been found by others not to be so correlated. The similarity of the effects

1 'Taken from the author's Dissertation "Comparative Anatomy of Citrus in Relation to Cold Irardiness," University of I'lorida, Cainesville, Fla, גpril 196.

${ }^{2}$ Professor of Torticulfure, College of Agrieulture, Eniversity of Puerto Rieo, Mayagïez, P.R.

"Ttalie numbers in parentheses refer to Lilenture Cited, pl). 334-fi. 
of freezing, drought, and heat on ecll dehydation has beon disoussed by Scarth (22) and Levitt $(13, /$ /).

Those physical factors involved in the retardation of water lose have ben considered as favomble or conducive, diectly or indirectly, to inareased tolorane to freching. Levite has, in fact, combined in the term "dchydration resistance" the tolerance to cold, drought, and heat (13).

Small rell-size has been found by Scurth (28), Shiclds (2/4), Siminovitel and Briggs (26), Leviti $(13,1 / 1)$, and Parker (18) to be the only constant and reliablo anatomical fonture associated with cold-hardiness. The ability of small cells 10 resist the injurious effects of freczing is due largely to their great surface-to-volume rutio. The large sulace is favorable for rapid cxosmosis and imbibition during freozing and thawing $(2,15)$. This redues the dehychation and rohydration stresses involved. Small cells possess small or no vacuoles (15), a factor which considerably redues the amount of water exchanged during frecaing and thaving. Arording to Parker (18), the redued water movement of snall cells mantains cellular organization close to a normal level during low temporatures.

Small cell-size may be a result of envirommontal conditions (4). Moisture stress, nutrient deficiencies, abundant illumination, or cold cluring do. velopment have been found to he factors induring the formation of smaller rells. The effect of the sfresses mentioned is responsible, within rertain linits, for the development of the xeromorphic type of leaf. Such laves have a thick andicle, a well-developed palisade, inerased overall loat thickness, increased stomatal density, and a woll-devcloped vascular system $(3,4,33)$. These at ributer may be associated with a rapid motabolio rate, furilitaling the arerumulation of photosynthates, increase in osmotic conecentration, and protection aganint desieration $(13,1 / 1)$.

A well-developed palisade has been resognized by Turrell $(30)$ as a feature which implies a large iuternal-to-external surlace ratio, a characteristic of xeromoryhs. Plants of this lype have been found to have a lower water rontent than mesomorphs, and a larger pexeentage of dry matlex (2/). Smith and Reuter (29) have found a larger perentage of dey matler in leaves of 'Valeucia' oramge in winter than in summer. Curtis and Clack

\footnotetext{
4 fingle chotes are used for varietat names in this paper following the Internalional Code of Nomendature for Cultivated Plants-1961, Regnum Vegetabile vol. 22, International Commission for the Nomenclature of Cultivated Plants of the International Luion of Biologiend sciences; Ut retch, Nelherlands. Article 17 of said code reads in parl: " $\Lambda$ rollivar (variely) bame, when inmediatcly following or preceding

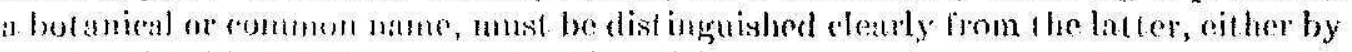
placing the ahbreviation cov. before the cullivar (variely) atane, or, for example, by cholosing within single gnotalon marks. * * Note: Domble quotat ion maks must. not be used to distingnish cullivar (valriety) numes."
} 
(2) have recognized that a lower water content in the tissues is conducive to resistance to ice formation.

Citru leaves have been found to possess two or three layers of palisade, depending upon the variety $(7,82)$. Halma found that palisade-layer number is not influenced by the stock upon which the scion is grafted (7). This proportion of the leaf ronreyponding to palisade tissue in citrus foliage was found to range from 21 to 30 perent, thus lowving a latge proportion of the leat mesophyll to the spongy marenchyma. Such a distribution of foliar mesophyll

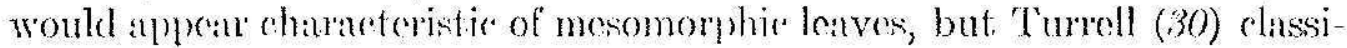
fied ritme leaves as xeromorphice.

Whether the amount of palisade in citus is a lavorable factor in the development of cold-hurdiness is open to argument. Palisade thickness in citrus was found to increase with age of the loaf, from a 2 -month-old fully expanded leaf to a 12-month-old mature leaf. This amounted to 5$)^{1 / 2}$ percent in 'Tureka' lemon (7).

Hirano (9) observed a certain relation between stomatal density in the citrus leat and the climatio distribution of the varieties. He concluded that densities of 500 stomates per sejuare millimeter or less were associated with cooler climentes and hardicr variotics. There are some noticeable exceptions to this romelusion. 'The hardy enlamondin (39) with 66i) stonates, and the tender 'Tahiti' and 'Boams' limes with 372 and 3206 stomates per sefuare millimeder, respectively, may be mentioned as such. Hiramo (9) conceded novertheles, that stomatal densily may bo more a result of moisture than of temperature. 'Thes, in hol, arid regions, stomalal domsitice have been found higher for the same valredy than in cooler mol moister areas (31). Similar observations have been made by Miller (17), Shickds (2/4), and Maximov ( $(6)$ ) for other plants.

A thick ruticle has been mentioned by Vasil'yov (3/) as a feature of plants exposed to constint low temperatures. Maximov ( $/ 6)$, Shiclds (20), and Philpott (19) Jave associated a thick antelo with xeromorphic louves. Harvey $(S)$ found that a waxy rovering provided protestion against icemucleation cluring frewing.

A small surface-fo-volume ditio has been observed by Shelds (25) ats a chatarteristic of leal" xeromorphy. 'This implies a smaller, thicker leaf, which is associated with a welleteveloped malisade and a relatively compact spongy puenchyma. Laves with such rhataderistics twatly have a more dense new work of veins. 'This adaptation to drought implies an etsier water'

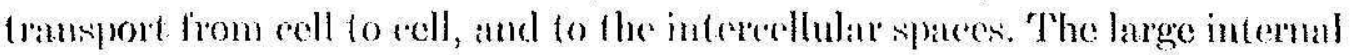

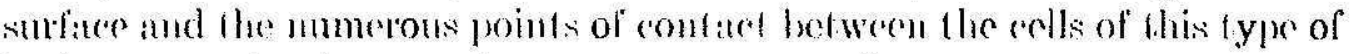
lable aceounts for the ease of walex novement (2.1). 


\section{MATERIAIS ANID METIOUS}

With the object of establishing possible polations berwen analonicat traits and rold tolerance, four varietes of citrus representing a wide variation in reerognized cold-hardiness were wededed. 'lhe plants used were grown from seed, and all varianls apperaing during flan initial is-month period of growth were eliminated. Criteria for elimination were departures from typieal foliage characteristics and unusually slow or rapid development.

The varicties selerted were, in desending order of observed cold-tolerance: 'Changsha' mandanin (Citrus reticulata), 'T'aiwanica' sour orange ( $C$. laiwanica), 'Parson Brown' sweet ormge ( $C$. simensis), and 'Mexican' ('West Indian') lime (C, antantifolia). This mang is bused on observations reported by various investigutors $(I, 0,10,11,32,34)$. "Taiwanica's sour orange has been observed by Krezdom (12) to be hardier under certain conditions than 'Changwha' maudarin.

The seedlings were grown in 10-(m. plastie pots in a greenhouse bench. After the plants were 5 months old, a series of them was plased in a controlled-elimate chamber for presonditioning treatment. This was done to investigate whether there occured any anatomical or growth ehanges as a result of the treatment, and to defermine the degree of cold-hardiness developed in each variety. The preconditioning cycle included a 12 -hour photoperiod at $26^{\circ} \mathrm{C}$. and a 12 -hour nyctoperiod at $2^{\circ} \mathrm{C}$. The night low wats gradually reached after 10 progressively cooler nights, starting at $14^{\circ} \mathrm{C}$. the first night. The total preconditioning treatment lasted 5 weeks, although freezing tests were made at the end of 2,4 , and 5 weeks.

The growth of the plants was recorded at $5,5 \frac{5}{2}$, and 6 monthe of age. Total height, foliation, aud branehing were observed. Lead areas were determined at the time of leaf sampling for mieroscopie examination. Speesific gravity and dry matter were determined from the eleventh emerging leal of each secdling. Microscopic examinations were made from the tenth emerging leaf of each plant.

Leaves were picked at 8:00 a.m. and placed immediately in at fold of moist filter paper in a plastic bag. They were stored in a refrigerator for the very short period between collecting and processing. Each leaf was surfacecleaned of possible deposits of dust and foreign matter with distilled water and a No. 6 camel's-hair brush, dried with bibulons paper, and weighed. The volume of the leaf was then delermined by immersion and measurement of (he displaced liçuid. After rinsing in distilled water, the leaves were pheed in individual paper bags and dried in a foreed drati oven at $70^{\circ} \mathrm{C}$. After storage in a desiceator for 48 hours they were weighed again. From the data obtained, specific gravily and dry malter were caleulated.

Vascularization was studied from whole cleared leaves after removal of 


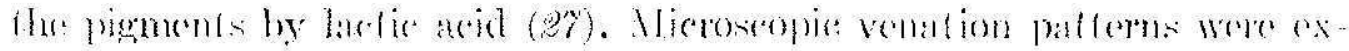

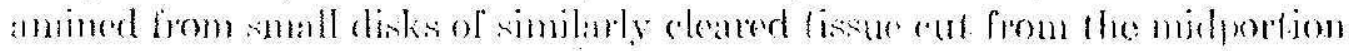

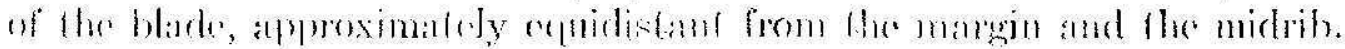

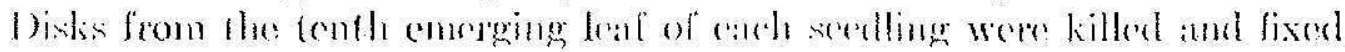

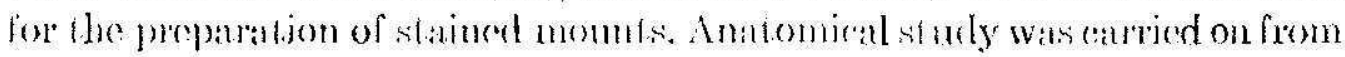
transections and patademal seedous of leaves and from tranverse, ladial, and tangential soetions of stems. lixing fudis lor Javes were formalinareto-alcohol and ahromic-acefo-formalin, and for stems formalin-acecoalcohol only. Staning was roulizely done with salman-last green (引l).

ficatures which were ameubble to meastrement wore selected so that the

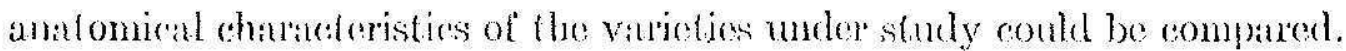
Theso included densitics of stomates, rystal idioblasts, oil ganels, and colls of epidermis, upper palisado, and fower palisude, as well as vein-termination numbers, areolar umbers, and inferveinal intervaks Lamina widihs, en-

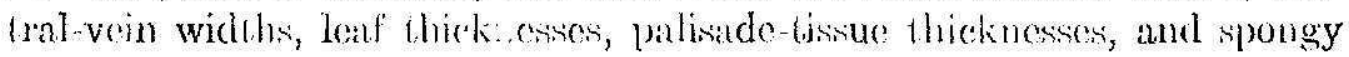
mesophyll thickneses were also measured, as were several other minor chanateristirs whidh may have a bonting upon cold-tolerance.

\section{MESULTS AND DISCUSSION}

The Preceng tests condueted after 2, 4, and 5 wooks of preconditioning revoaled results which did not conform in all respests to the areopted cold. tolerance rating of the varieties under study. After 2 woeks all plants survived a freezing temperalure of $-4{ }^{\circ} \mathrm{C}$. for 1 hour. After 4 weeks the ireezing temperature uned was $-7^{\circ} \mathrm{C}$. for 3 hours. An additional test was also mate at is wooks. The resuls of the second and third test alppoar as test I and test II in table 1. Control plants in test I hal been kept in a conbolleddimate ohumber similar in illumiution to the preconditioning chamber, but under a cycle including fivomable temponatures for growth. Control plants for test II were brought directly from the greenhouse.

The preconditioning secuence, the growth conditions, and the freczing tests as carried out in this investigation apparenty indued a marked degree of cold tolerunce in 'Mexic:n' lime, but did not do so in 'Parson Brown' sweet orange. "The overall seore for hathess oblaned by the four varieties placed them in the following odder: '(hangsha' mandarin fiest, followed by 'Mrexican' lime and 'l'awanica' sour oramge wilh guite simalar scores, and 'T'arson Brown' sweet orange last. 'The natuml hardiness of plants direct from the grenhouse placed these variedies in desending order as follows: 'T'aiwanica', 'Changsha', 'Mexictus', and 'Parson Brown'.

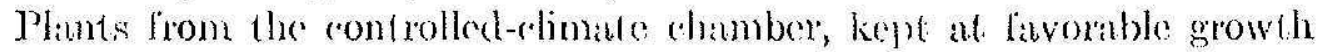
temperalutes, showed cold-lolexune in the order: 'Changsha', 'Mexican', 'Taiwanisal, and 'Passon Brown'. Finally, the combined numerical score obtained from nonhartened plants in the two tests, was in the following 


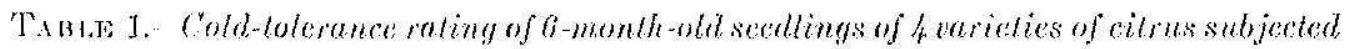
(o) $-7^{\circ}$ C. for 3 hours

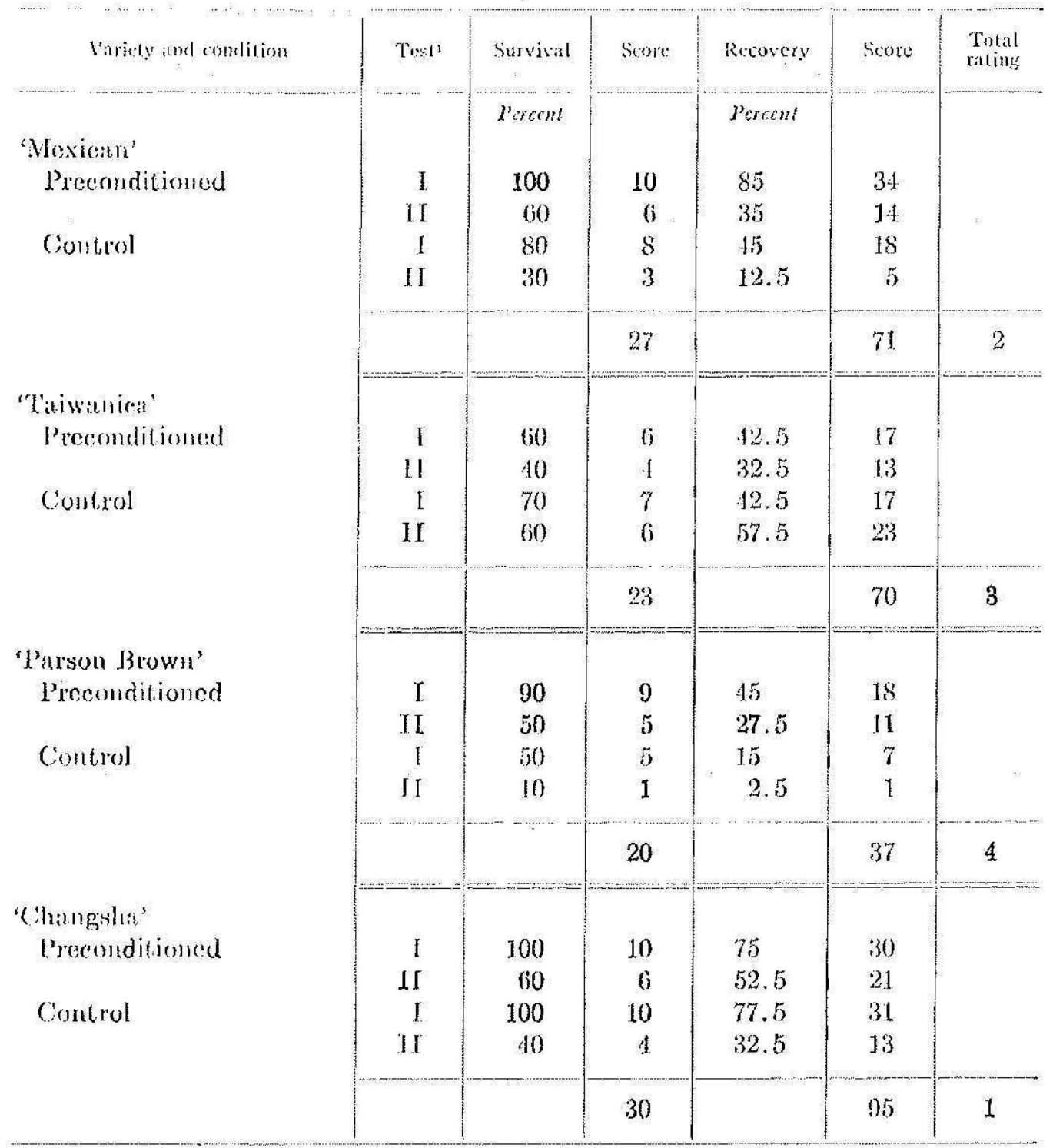

1 Tests I and II after 4 and 5 weeks of preconditioning, respectively. Survival rating sehedule:

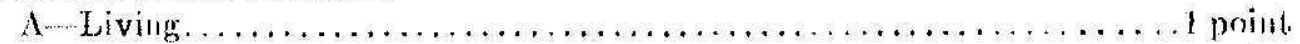

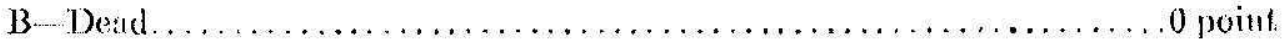

Pereent sirvival $=\mathrm{A} \times \mathrm{L} \times 100 /$ mumber of plants

liecovery riting schedule:

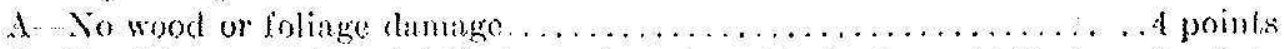

13- l'artial or complete defoliation or less than l. iuch of wood killed....3 points

C. One-thind to three-fourths wood killed . . . . . . . . . . . . . . . 3 points

D - Killed to ground level, but sprouting .................... 1 point

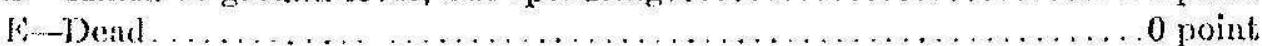

Percoutage Recovery $-\frac{25((.1 \times 1)+(B \times 3)+(C \times 2)+(I) \times 1))}{\text { Number of plants }}$

Total rating $=$ points liecovery + points Survival 
order: 'Changshe' mambrin first, followed rather alosely by 'Tawanicit' sour orunge, 'Mexicun' limo third, and 'Pason Brown' sweet orange last.

'The low degree of colet-toleraues shown by 'Pason Brown' sweet orange and the relatively high score of the normally tendex 'Alexican' lime seem to indieate that different varieties require a different set of growth eonditions before the onset of freeging temperatures, which is not identical for all vareties. When these conditions are not met, cold-hardening cloes not take place.

In. tahle 2 are summarized the growth in height, and the leat expansion in secollings of the four varetios when kept under lavorable growing eonditions

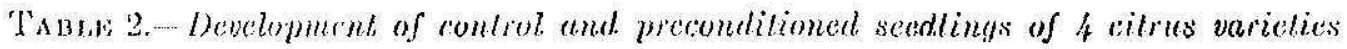
between 5 and 6 months of age

\begin{tabular}{|c|c|c|c|c|c|c|}
\hline \multirow{2}{*}{ Varricty and condition } & \multicolumn{3}{|c|}{ Height } & \multicolumn{3}{|c|}{ Expanded leaves } \\
\hline & $5 \mathrm{mos}$. & $0 \mathrm{mo}$ & Change & $5 \mathrm{mo.}$ & 6 mo. & Clange \\
\hline & $\mathrm{cm}$ & $\mathrm{cm}$. & $\mathrm{Cm}$ & Number & Number & Numbicr \\
\hline \multicolumn{7}{|l|}{ 'Mexic:u' } \\
\hline Control & 37.2 & 39.6 & 2.4 & 29.0 & 30.9 & 1.9 \\
\hline Preconditiones & & 30.1 & 1.9 & & 30.7 & 1.7 \\
\hline \multicolumn{7}{|l|}{ "Changsha" } \\
\hline Control & 18.4 & 22.8 & 4.4 & 17.5 & 21.7 & 4.2 \\
\hline Preconditionserl & & 19.2 & .8 & & 20.2 & 2.7 \\
\hline \multicolumn{7}{|l|}{ 'Parson Browle' } \\
\hline Continal & 33.2 & 37.1 & 3.9 & 18.4 & 22.6 & 1.2 \\
\hline Preconditioned & & 35.5 & 2.3 & & 21.3 & 2.9 \\
\hline \multicolumn{7}{|l|}{ 'Taiकมлиса" } \\
\hline Conirol & 31.6 & 36.7 & 5.1 & 20.3 & 24.6 & 4.3 \\
\hline Preeondilioned & & 33.7 & 2.1 & & 22.3 & 2.0 \\
\hline
\end{tabular}

and under preconditioning temperatures. The greatest stem elongation was made by 'Taiwanica' and 'Changsha' under control conditions, and the most marked depression was also observed in these wo varieties under pre('onditioning forneratures (fig. 1). This secms to indicate that these varioties initiate tormancy soon after the temperature begins to fall. 'Parson Brown' and 'Mexiean' were depressed less in their growth by low night temperatures.

Thus, under cold nights 'Changsha' male only 18 pereent as much growth as the control plants, 'Tawanica' 41 percent, 'Pawon Brown' 58 percent, and 'Mexican' lime 78 pereent as much, respectively. A direct relationship stppears to exist between the depression of growth unler cold nights and the cold-tolerames of the variety.

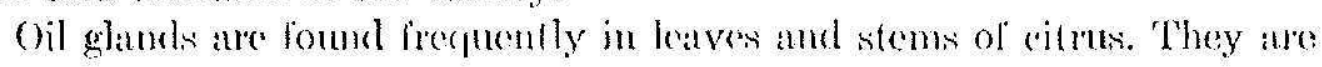


generally close to the epidermis and may bo observed as drantueent spots. Total oil-gland density in seedling leaves was found to boa no apparent relationship to cold-hardiness. The proportion of oil glands between the upper and the lower epidermises was variable, according to the variety. 'Thus, 'Mlexican', the tenderest variety, had 3 times as many oil glands in the ventral eprdormis as in the dorsal, 'Parson Brown', and 'lawanien' had

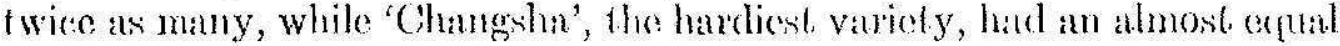
number in both faces of the lamina (fig. 2). It is not known what eflect oilgland distribution mily have upon cold-hardinoss, but the find remains

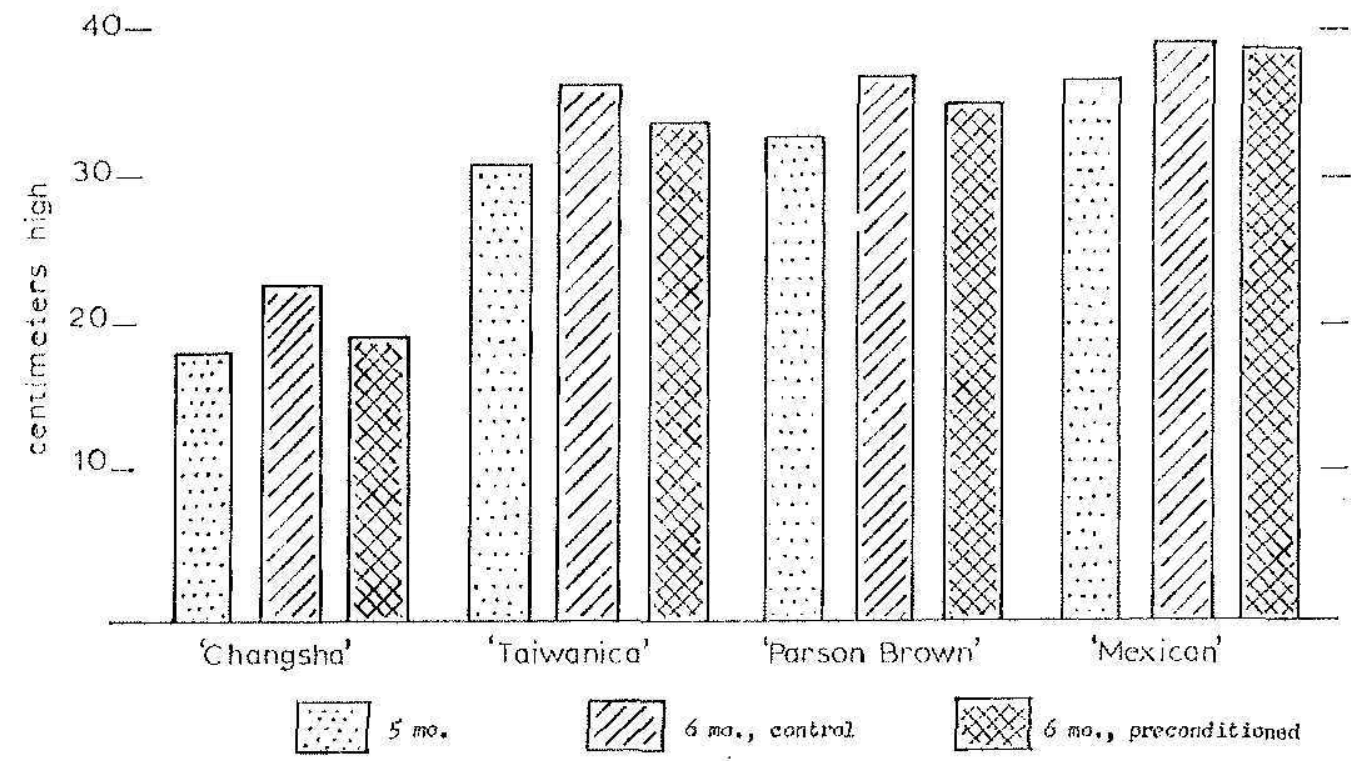

Frs, 1.-- Effect of preconditioning on stem elongation in seedlings of 4 citrus varielies.

that the more evenly distributed the oil-glands, the more cold-tolerant the variety appens to be. The total number of oil-glands per square millimetor in these varieties were: 'Mexican' 1.46, 'Changsha' 2.74, 'Pason Brown' 1.91 , and 'Taiwanica' 1.37 .

Stomalal counts made on control plants showed a slight increase between 5) and 6 months in 'Changsha', 'Parson Brown', and 'Mexican'. 'This was not observed in 'Taiwanien'. Preconditioned plants had stomatal counts similar' to the means obtained from the control plants. This supports the observations made by Recd and Hirano (20) to the effect that, stomates aro formed early in the development, of the leaf. The relutively low stomatal counts obtained were attributed to the lowered illumination under which the seedlings were grown. No correlation seemed to exist between stomatal counts and cold-hardiness, as the hardiest and the tenderest varieties had similar 
counts (fig. 3). The average number of stomales per separe millineter in these varietios were: 'Mexien'-124, 'Changsha'-112, 'Patson Brown'-398, and 'laiwanica'-362.
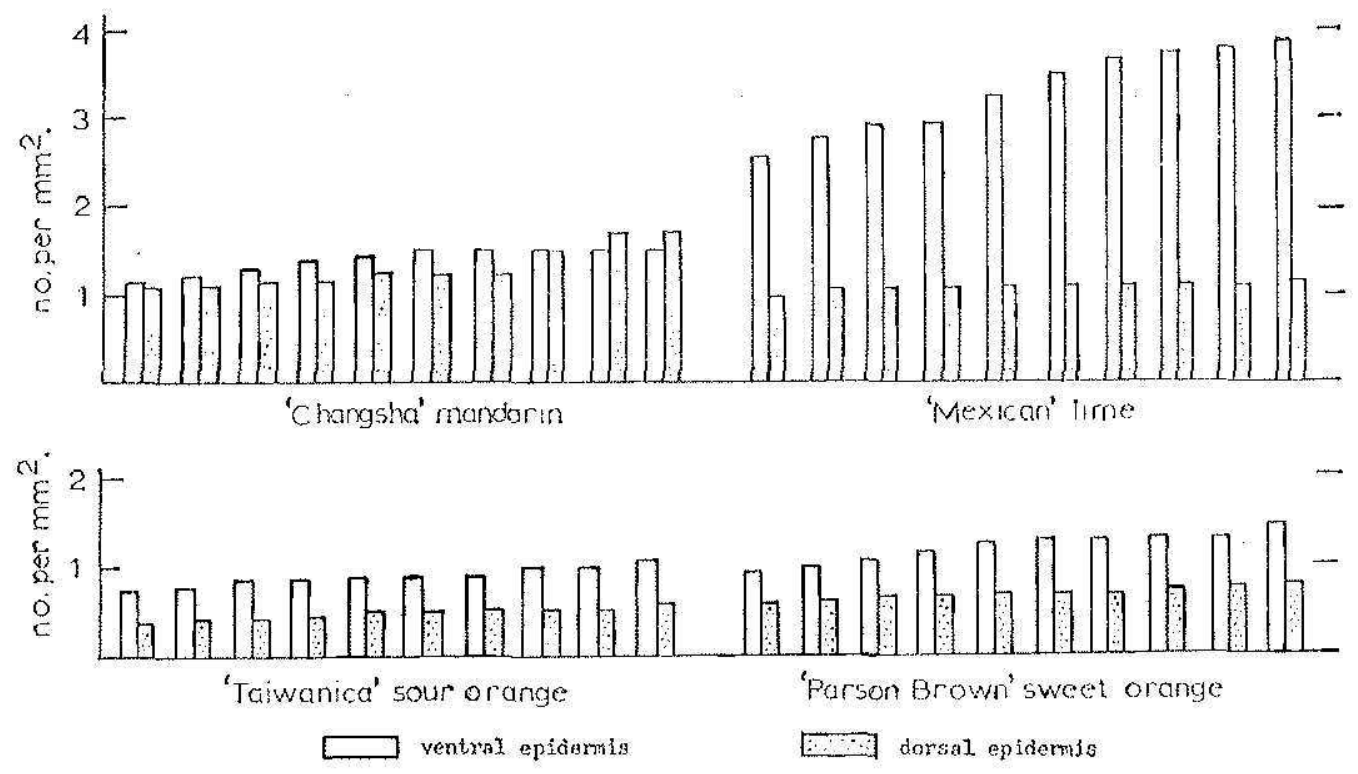

Fra, 2,- Oil-gland densilies in Inaves from 10 different seedlings of each of t witrus varicties.

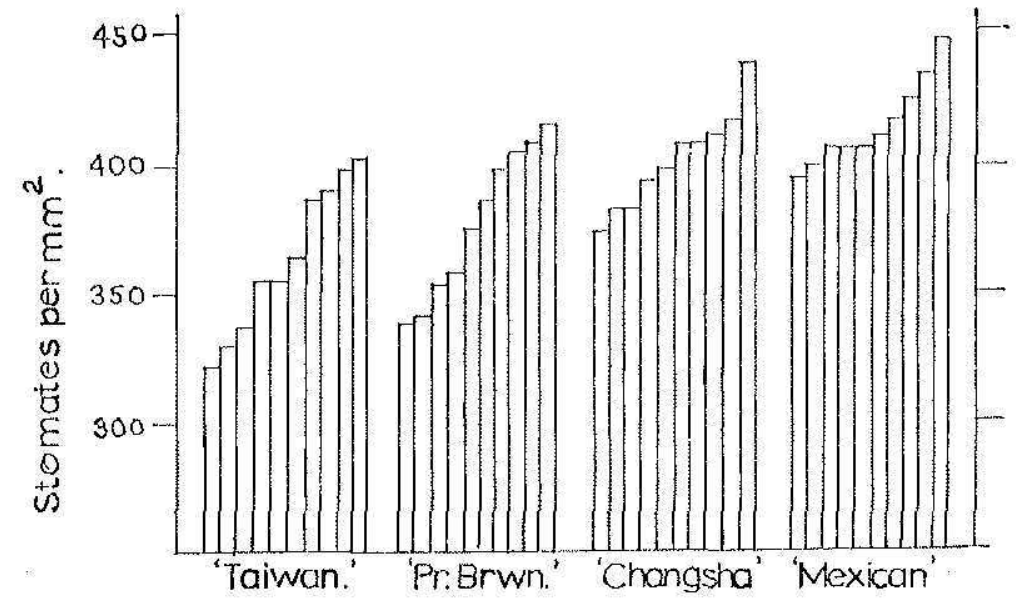

FIG. 3. Stomatal deusities in dorsal epidermis of leatyes from 10 different secdlings of each of 4 citrus varielies.

Crystal idioblasts occurred in parenchymatous bissues of all acrial parts of the plant. These idioblasts are very conspicuous because of their size and the thick cellulose wall which stains decply. The tenderest variety, 'Mrexicau', had 947 idioblasts per square millimeter, twice as many as the hardiest variety, 'Changsha,' which had 455. 'The ofher two varoties, 'Tarwanica' 

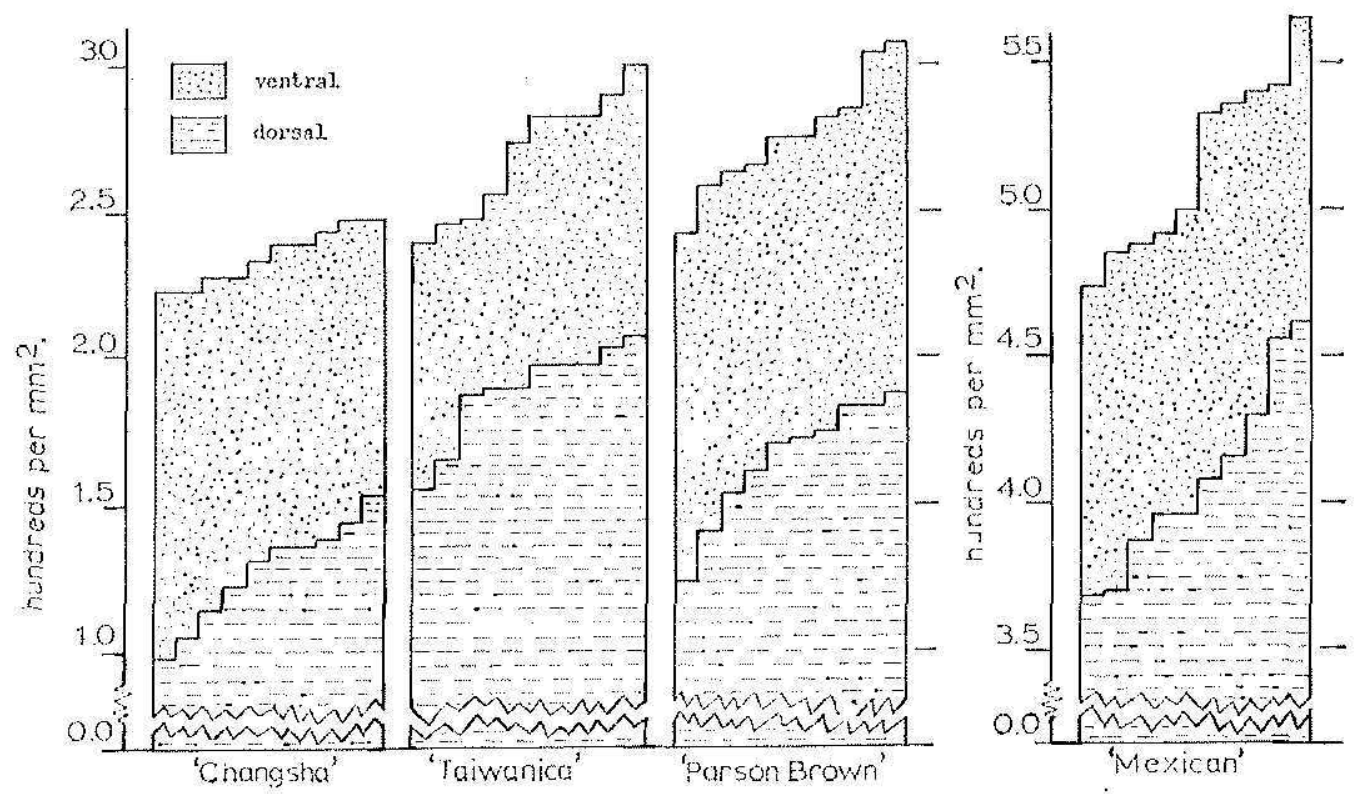

Fut, 4.-Crystal-ilioblast densities in vent,al and clorsal epidermises of lenves from 10 different secdlings of each of 4 eitus varieties.

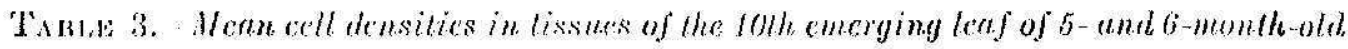
sectllings of \& citrus wricties

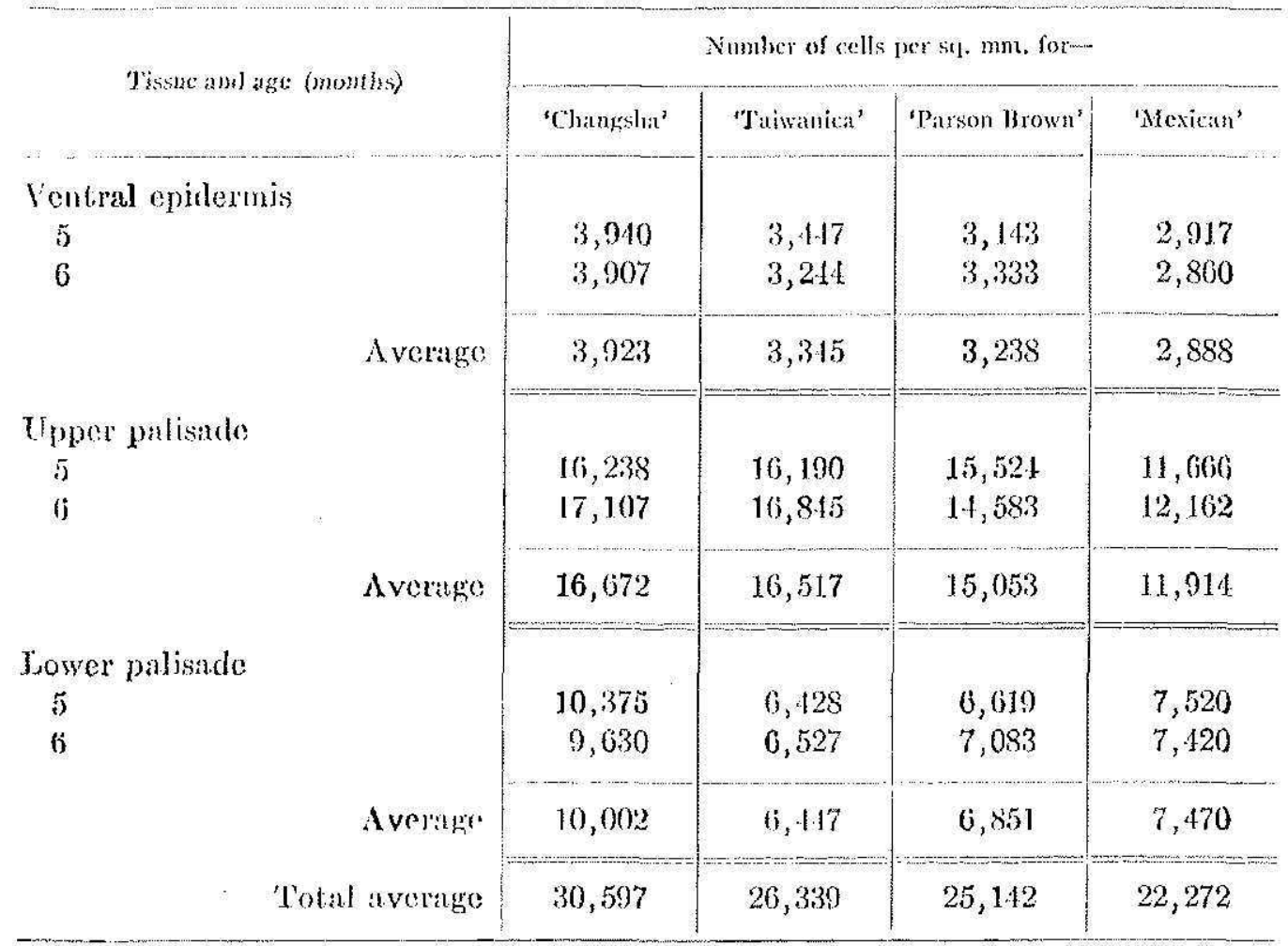


A

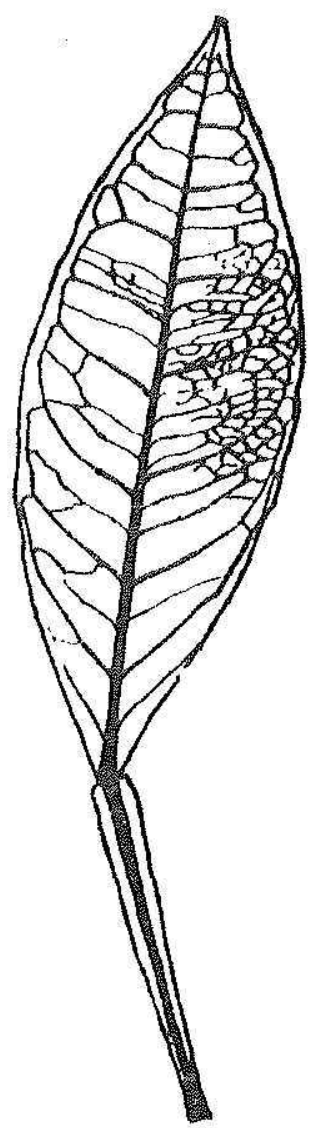

C

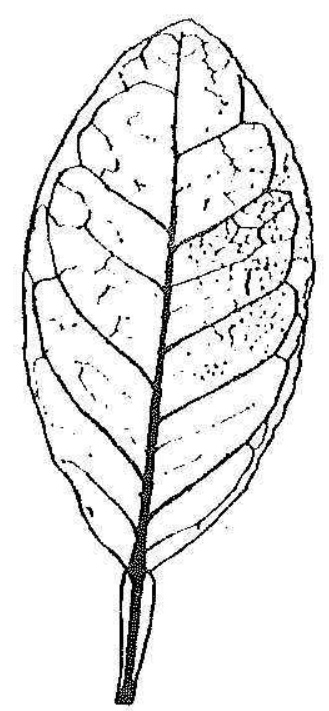

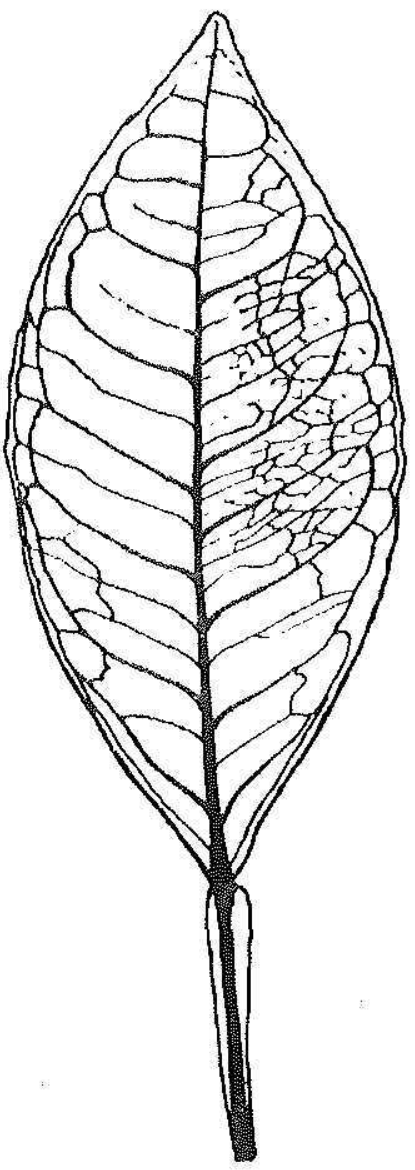

B

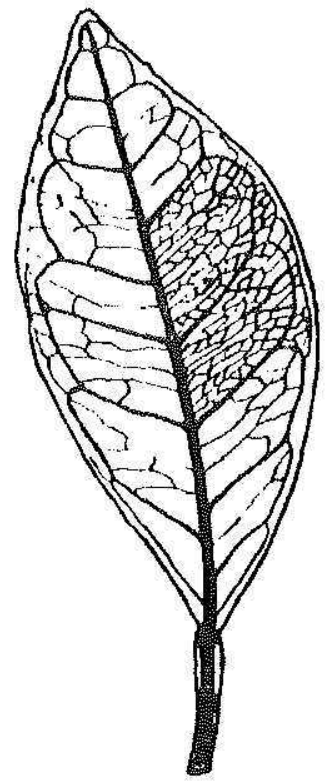

1)

Fro. 5, Main vestation in seedlings ol I rifers varielics: A, 'Taiwanica' sour orange (C. Leivunion); B, 'Parson Bown' sweet orunge (C'. sine'usis); $\mathrm{C}$, 'Mexiean' lime (C. aurantifolia); D, 'Changsha' naandarin (C. reliculala). 


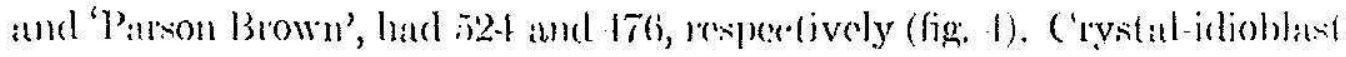

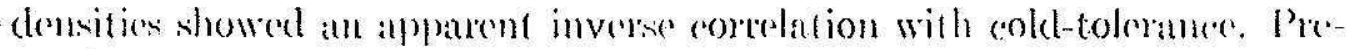
ronditioning by cole seened slighty to reduce idioblast fommtion, as suggested by the comistently lower means of ald troated plants as eompuned with the eontrols.

Three fissurs of the lad having a relatively orderly organization were noed

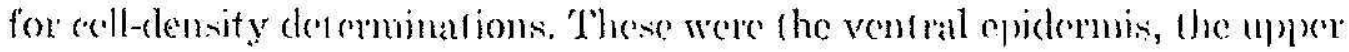

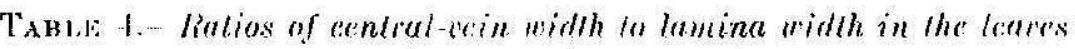
of scedlings of 4 cilrus andelies

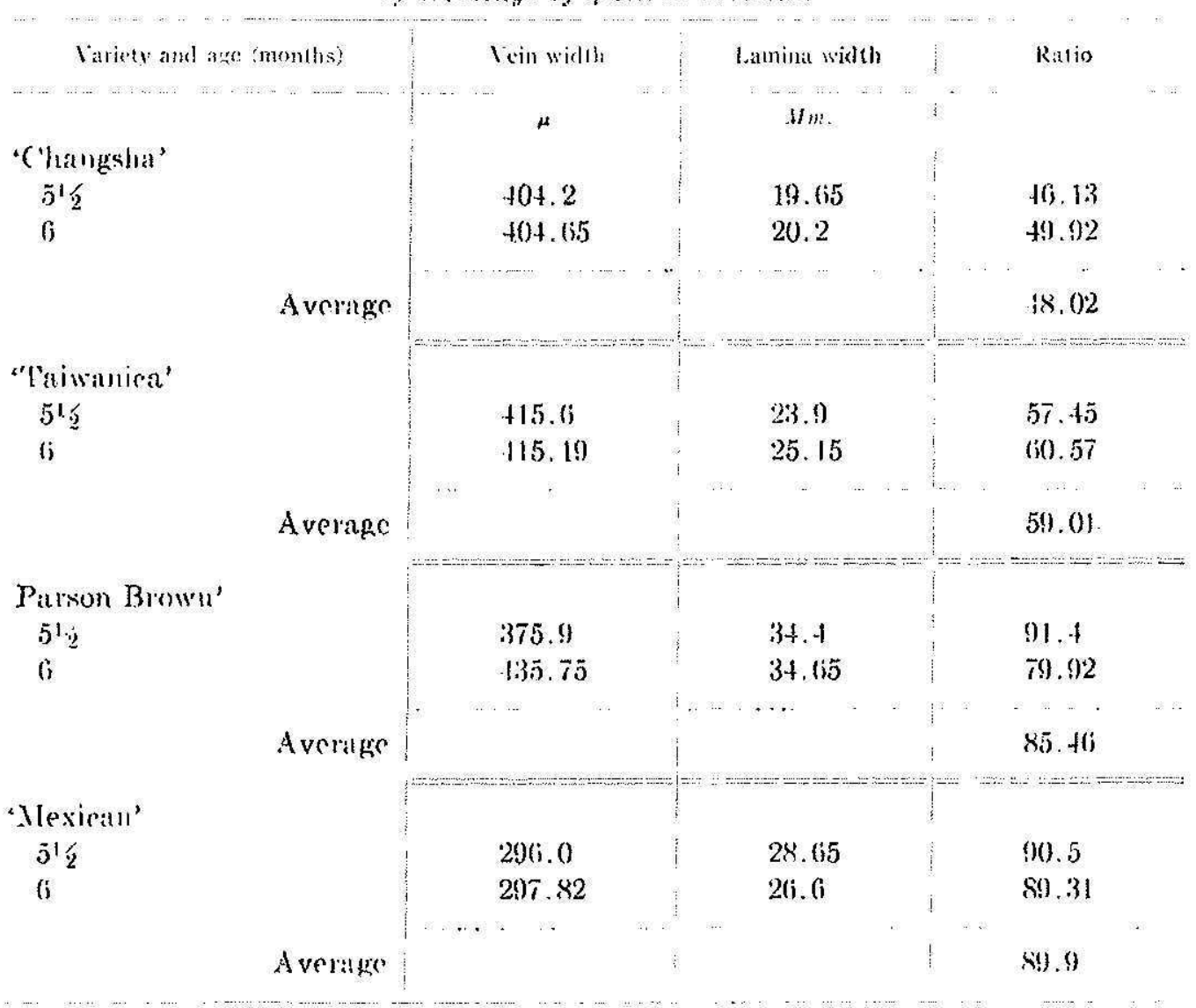

palisiade and the lower palisade. The values observed are included in lable 3. 'The total cell-deusity of the theo tissues mentioned, as woll as that of the upper epidermis or the upper palisade laken alone, appen to bear a direce reliationship) with rold-toleriuce.

At (i) monthis of age leaf-thickness averages were: 'Parson Brown' $2+1 \mu$, 'Changha'-226, 'Mlexic'an'-211, and 'Tawanica'-209, while paliwade thick-

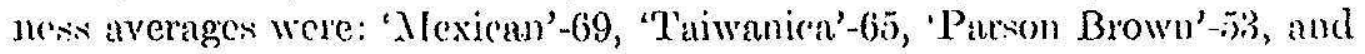
'Changhal' $62 \mu$. The proportion of the leaf oceupied by the palisade as: seen in tratsection was: 'Mexican'-32 percent, 'Taivanien' 31 perrent, 

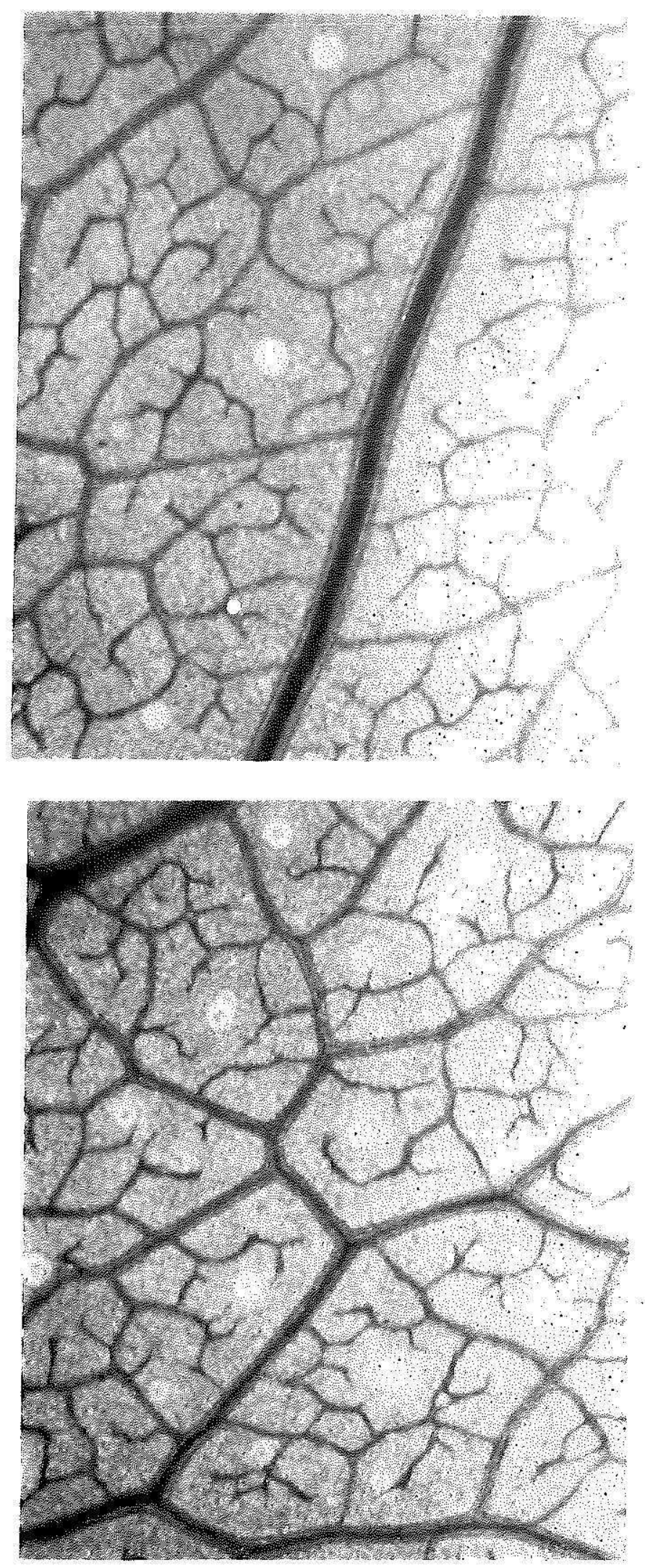

Fis. 6.--Microsenpic venution patterns of seedlings of four different citms varieties. (All $2(\mathrm{X} X)$. 

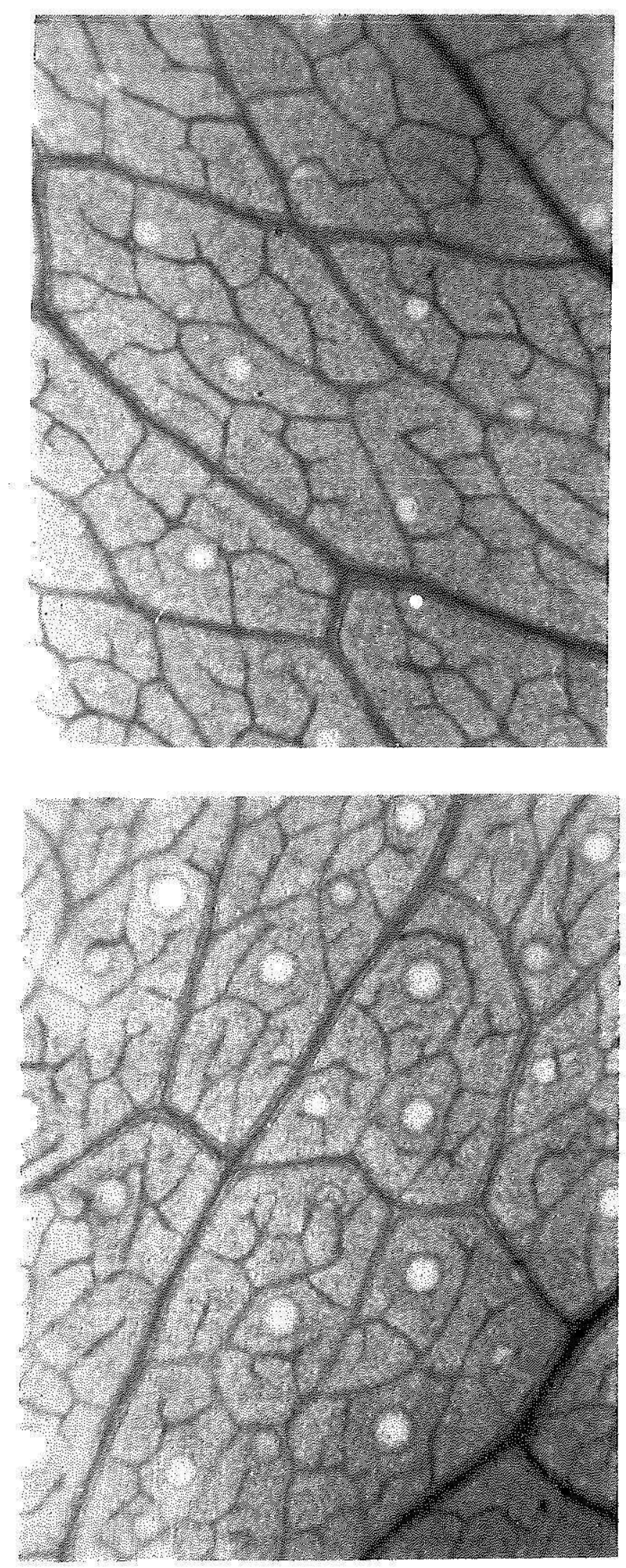

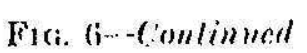

329 
'Changsan'-17 pereent, and 'P'aron Brown'-26 pexcent. Firom the above figures it appears that leat- or palisade-tissue thicknesses are not related to rold-hatediuness of the varied ins enurerued.

Taseulariation ehatacteristios as to vein dist libution, inferveinal spareing, rein lerminations per sefuatr millimeler, and areolat frecueneies, did not have a ronsistent rolationship) 10 rold tolerance (figs. is and (6). The width of the eental vein, nevertheless, was found to be meportionately thicker in the hatelier varieties. Comparing the vein width to the wislth of the lamina, it was foumd that this ratio was natrower in the hadies varice-

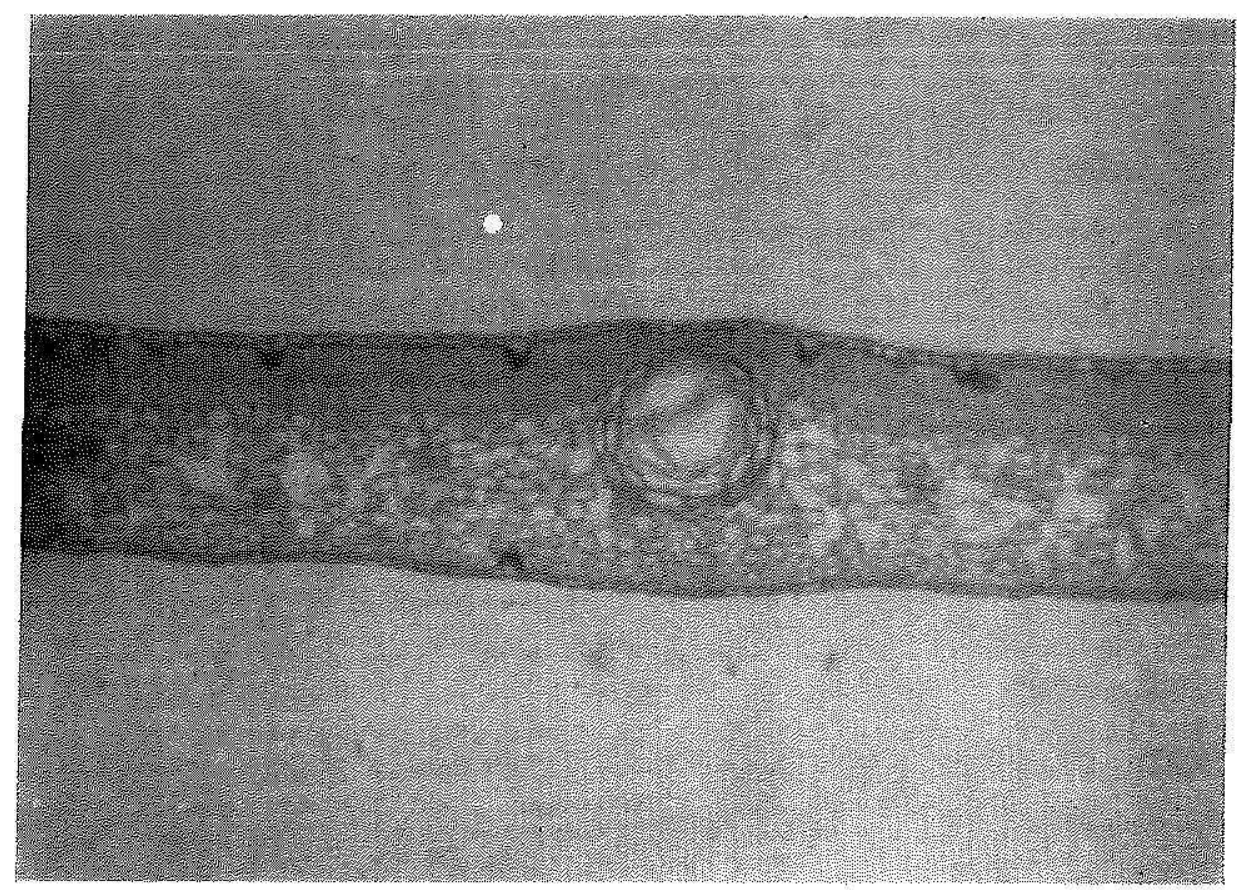

Fra. 7.--lsat transertion of 'Chaugsha' mandarin: Jurge oil gland, small-celled palisadc, and compact spongy mosuphyll; crystal idioblasis relatively near to oilglands. $(75 \times)$

ties. Table + shows the values observed and the calculated ratios. As will be seen, the nayrowcst ratio is that in 'Changsha' mandarin, the hardicst variely, and the widest ratio in the tenderest, variety, 'Mlexican' lime. The other two varietice also have ratios proportional to their areepted hardines: when compared with 'Changsha' and 'Mexican'.

Both the surecific gravity and the dry matter of all the varicties increased under favorable growing ('onditions from i) to 6 months of age. Plants under cold nights surpassed the controls of comparable age in spesific gravily and in dry matter. The highest increase in specitic gravity affer preconditioning was shown by 'Changxh' mandarin and 'Mr'xi'an' lime. These nere also the ino varieties witl the highest cold-tolerance seore in the frewing tests. 

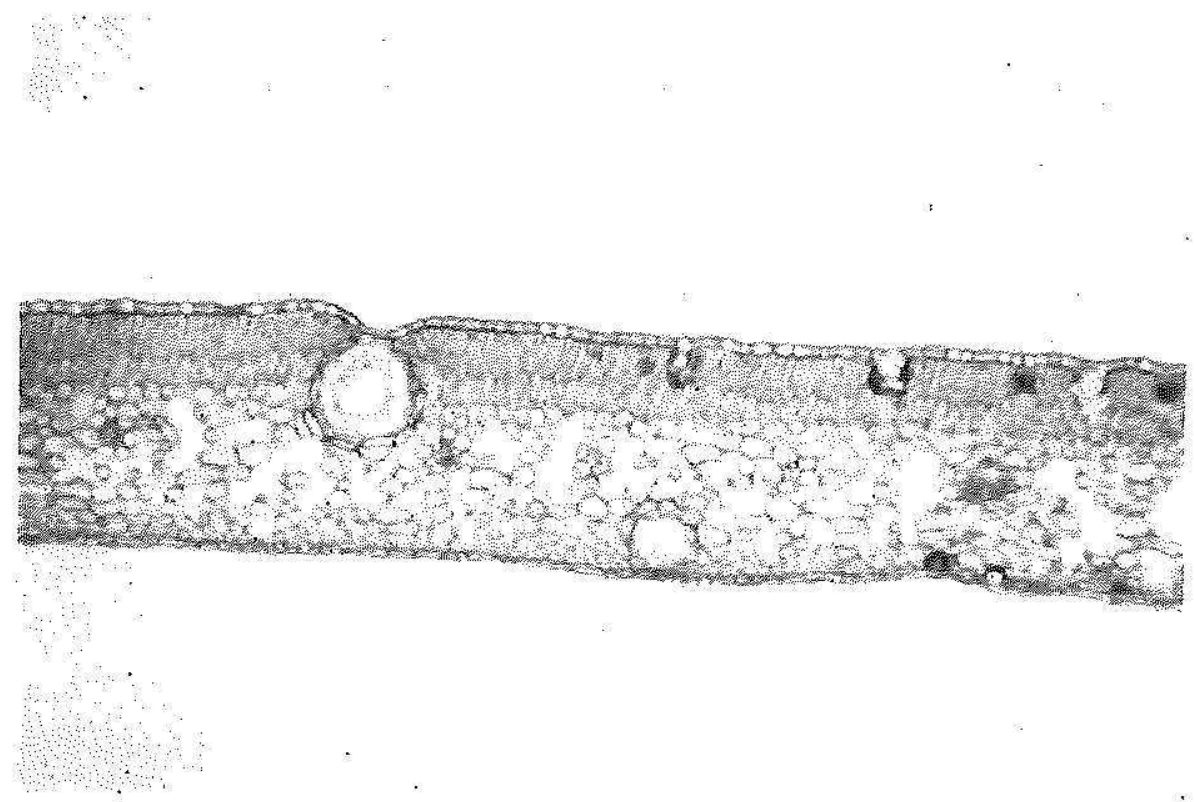

Fic, 8.- Leaf transection of 'Parson Mrown' sweet mange: Medium-sizd oil glands and loose spongy mesophyll; erystal idioblasts away from oil-glands. (75x)

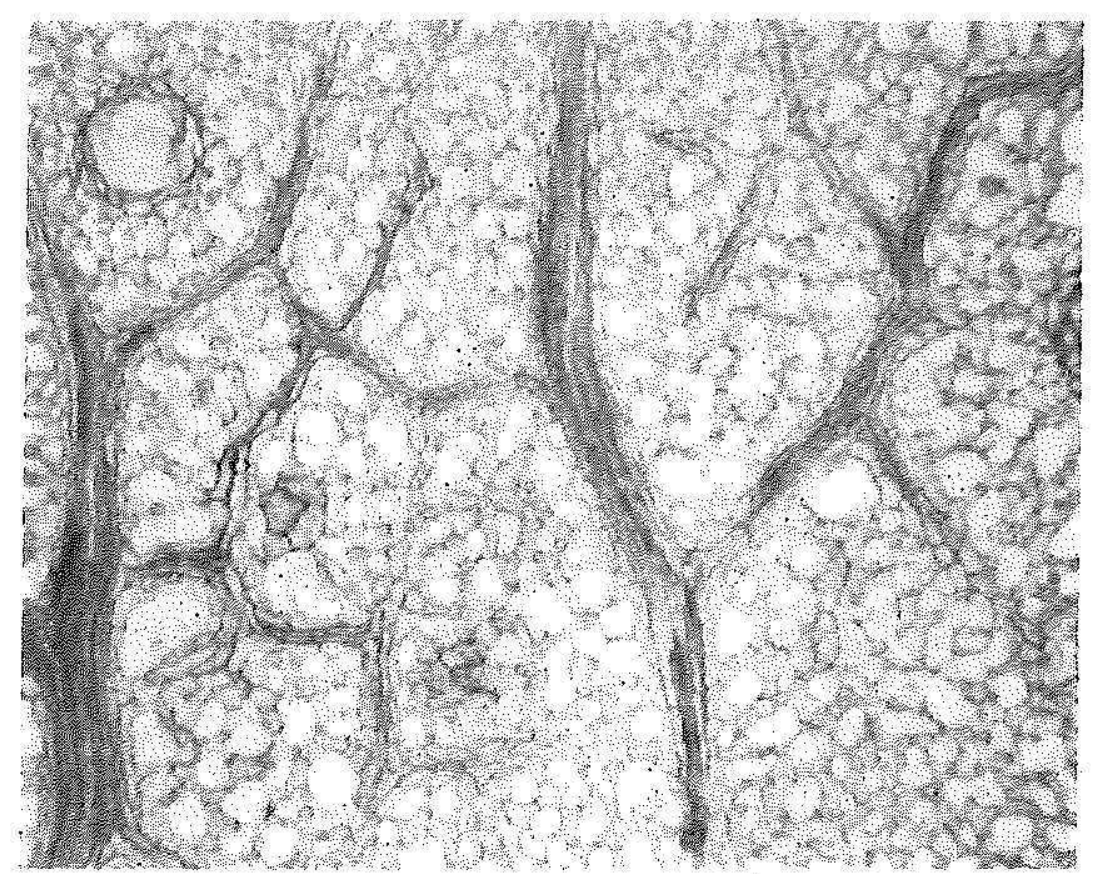

Frt. !. Paradermal section of leat of 'Changsha' mandurin: Midleaf scetion showing relatively compact spong. mesophyll. $(75 \times)$

Preconditioning indued a higher asceumulation of dry matter in three of the four varietices in the following order: 'Changsba', 'Taiwanien', and ' $\lambda$ fexican'. 'Patron Brown' phants had a lower dhy-matere content at (6 ham an is months. Dry-matlex arecumulation followed the rating obtained by these 
rarielies in resperl to survival and resovery when fromen without preronditioning, as can be seen in table 1.

In ligures $7,8,9$, and 10 the more compunet mature of the lat lisites of 'Changsha' mamblain as rompared with those of 'Parson Brown' sweet oratge and the 'Alexican' lime can be apprecrated.

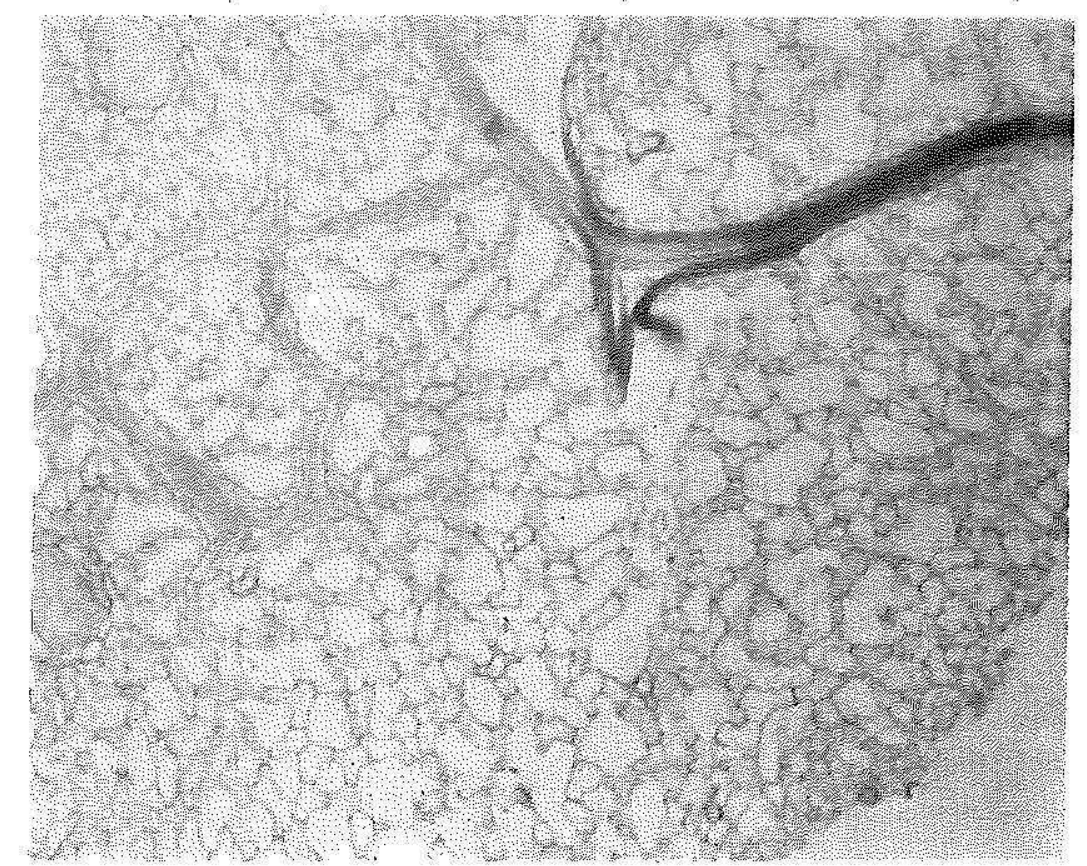

Fri. 10. Pardermal section of leat of 'Mexicun' lime: Midleat section showing open lype of spongy mesophyll. (75X)

\section{SLMMARY ANIO CONCLUSIONS}

Secdlings of four varieties of citrus were used, representing four speries with a rauge of rold-tolerunce from high to very low. They were examined auatomically and the findings mated to the areepted cold-tolerance of the varieties and with their porformane in freeming tests.

The varieties selected were, in desending order of rold-lolerance: 'Changsha' mandarin ('ilius reliculala); 'Taiwanica' sour orange (c'. Laiwanica); ' $\mathrm{P}$ :uson Brown' sweet orange (C. sinensis); and 'Мexican' ('Wost. Indian') lime (C. auranlifolia).

It was concluded from the results of these tests that a given preconditioning treatment, may induce in the plants subjected to it an ability to endure cold, which may not be consis(ent with their accepted tolerance to sold.

A definite inverse relationship) botween growth-rate and cold-tolerance was found in lar plants under inverigation. This growth-rate was more depresied in the hatrdier virietics when they had been subjected to a preconditioning tratment. 
There appeared to be wo relationship between total oil-gland routent and cold-hatediness, but if was found that, il ventral and dorsal mumbers were nearly ceptat, the plants were more resistant to rold.

Stomatal densities, under the rombtions of this investigation, did not. show any redation to the areepted folerane to cold of these variedies, or to thein tolexanes in the freeging tests.

C'aleium oxilate idioblatsis appeated to ocrum in the leaves of citrus in cumutities inversely proportional to areepted tolerane to sold.

There was apparently no correlation between the thickness of palisade as perentage of total thiekness and rold-toleranee in the varieties studied.

The number of eells per square millimeler in the upper palisade parenchymat of the leaf, ax well as the combined total edell rontent of the paliside

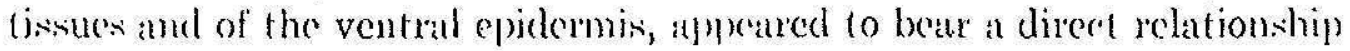
to the areepted cold-tolerane when compruing the four varioties studied.

Among the varietion in this investigution, there were no appreciable differenes: in the pattern of the major veins of the leat. It wis found, neverthelcis, that within a varicty there was a relatively anstant ratio of the width of the central vein to the width of the lamina. The numerical value of this ratio was found to be inversely proportional to the cold-toleranes of (he variely.

'There alpleared to be no relation in the varietices studied between cold hardiness and areolar frequencies, intervaseular intervals, or vein-temination numbers.

Precoudifioning by cold brought about a greater increase in sperific: gravily and dry mallor in the hardier vartulins, between the ages of is and 6 monthe, as comprated with the controls.

lianly branching and early formation of lenticles and eork in the "Xexi(an' lins: and the 'Parson Brown' sweet orange, as rompared with 'Taimanica' sour orange and 'Changsha' mandarin, secmed to be inversoly correlater with rold-resistance.

\section{RESLIMEN Y CONCUUSIONES}

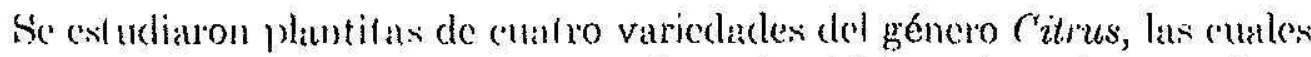
represenfaban cuatro espeeries, cuya tolonurcia al frío vmiaba de muy alta a muy baja. So hi\%o un examen de ha plantilas y sc asociaron los resultados

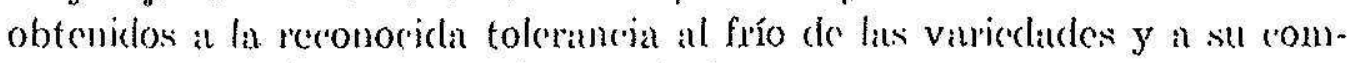
portamiento en las prucbas de rongelatrión.

De los resultados de estas prucbas, se concluyó (que al aplictíseles un trat lamiculo preacondicionador a las phantitas puede inducirse on estas una rapacidad de resistencia al frío que no coincida ron su reronoedala toleman(iia.

Jín las plankas bajo estudio se encontró ma relación inversa definitiva 


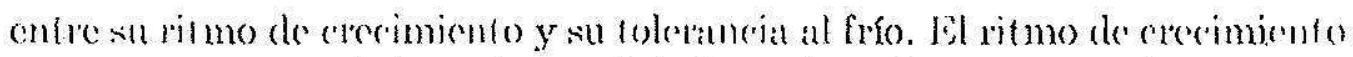
(ra menos promureiato en las variedades más resistenfes cuando se some-

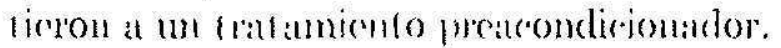

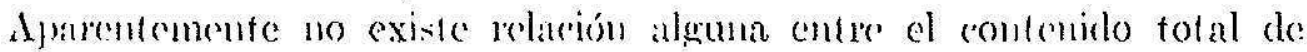

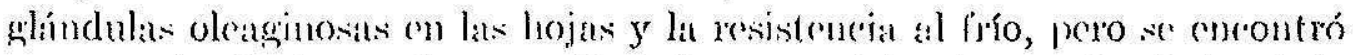

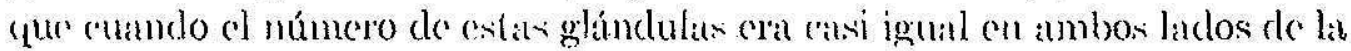

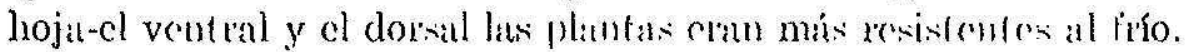

'Tamyoco sce encontró, bujo lats coudiciones de este sstudio, ninguna relat-

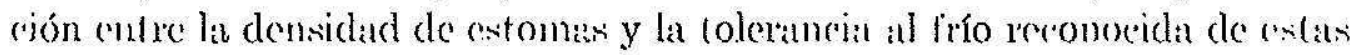
variedades ni con su tolemancia en las pruebas de congelarión.

Los idioblastos de oxulalo de calcio en las hojas del género Citrus, pare-

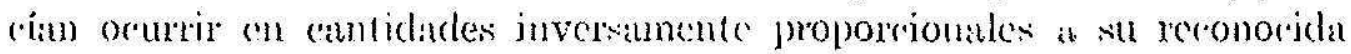
tolerancia al frío.

Aparentemente no existia conelarión alguma cula el sopesor de los tejidos en forma de palisada y la 1 blerancia al frío en las variedades est udiadas

Gl número de células por milímetro cuadrato en el parenquima de palisada superior, tanto como el contenido tolal combinado de las células de palisada y de la epidemis ventral do lia hoja, pareció tener una relación directa con la reconorida rolerancia al frio al compurarse las cuahro variedades bajo entudio.

Entre las varicdader bajo rifudio no se obrevaron diferemeias apreciables en el diseño de las venas principales de la hoja. No obstante, se encontró que dentro de una misma varicdad existíl ma proporción constante entre la anchura de la vena central y la anchura de la lámina. Se enrontró que el valor mumérico de csta proporeión es inverwamente proporeional a lat tolerancia al frío de la variedad.

No patueció existir relación alguna en las vaiodades cotudiadas contue su resistencia al frío y lis freeuencias areolates, intervalos intervaseulares, o el número de terminariones de venas.

id prearondicionamiento por rufriamicnto provosé un atmento mayor

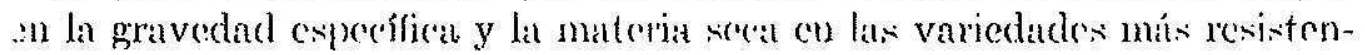

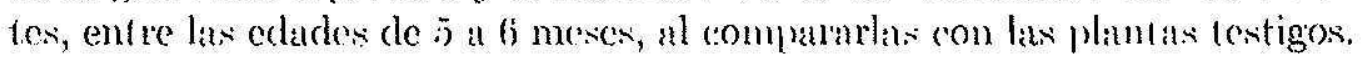

La formación templana de ramas, louíreulos y coreho en la variedad 'Mrexican' de limón y en la china dulec 'Parson Brown', parceió extar in-

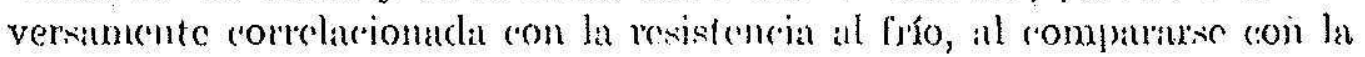
variedad 'Tawamir'a' de marunja ngria y la mandarina '( 'hangsha'.

\section{LTERATURE CITED}

1. Chandler, W. If, livergecen Orchatds, 2nd ed., Lea \& Fohiger, Phila., Pa,, 1958.

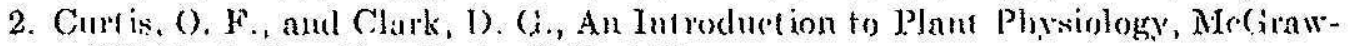
Irill l3ook Co., Now York, N.X., 1950.

3. Lames, A. J., and Mel)aniels, I. II., An Inforluetion to Jant Anafomy, 2nd ed., Marira-IJill Buok Co., New York, N.X., 1947. 
4. Esan, Katherine, Anatomy of Seed Plants, John Wiley \& Sous, Ine., New. York, N.Y, 1961.

5. Furr, J. R., and Armstrong, W. W., Breeding eitus for cold hardiness, Proc. Fla. Stale Horl. Soc. 72: 66-71, 1959.

6. Gerber, J. F, personal communication, Department of Fruit Crops, Univ. Fla.: Gainesville, Fla., 1964.

7. Halma, F. F., Quantitative differences in paliside tissue in citrus leaves, Bot. Gaz. 87: 319 24, 1929.

8. Harvey, R. B., Hardening processes in plants and development from frost injury, $J$. Agr. Res. 15: 83-112, 1918.

9. Ilirano, $\mathbf{F}$, Relative abundance of stomata in Citrus and some related genera. Bot. Gaz. 92: 296-310, 1931.

10. Hodgson, IR. W., Schroeder, C. A., and Wright, A. W., Comparative resistance to low winter temperatures of subtropical and tropical ruit plants, Proc. Amer. Soc. Hort. Sci. 56: 49-64, 1950.

11. Hune, H. IY., Citrus Fruits, Maemillan Co., New York, N.Y, 1957.

12. Krezdorn, A. H., Personal communication, Department of Fruit Crops, Univ. Fla., Gainesville, Fla., 1964.

13. Levitt, J., Frost, drought, and heat resistance, Ann. Rev. Plant Phys. 2: 245-68, 1951 .

14. - - The Hardiness of Plants, Acudemic Press, New York, N.Y., 1956.

15. Levith, J., and Scarth, G. W., Frost hardening studies with living cells. II. Permeability in relation to frost resistance and the seasonal cycle. Canad. $J$. Res. 14 (C): 284-305, 1936.

16. Maximov, N. A., The Plant in Relation to Water: A Study of Physiological Basis of Drought Resistance (translated by R. H. Yapp) George Allen \& Unwin, Ltd, London, Eng., 1935.

17. Miller, E, C., Plant Physiology, MeGraw-Hill Book Co., New York, N.Y., 1938.

18. Parker, J., Sol-gel transition in the living cells of conifers and their relation to their resistance to cold, Nature 128: 1815, 1958.

19. Philpott, Jane, A blade tissue study of leaves of forty-seven Ficus species, Bot. Gaz, 115: 15-35, 1950.

20. Reed, H. S., and Hirano, E., The density of stomata in citrus leaves, $J$, Agr. Res. 48: 209-22, 1931 .

21. Sass, J. E., Botanical Mitrotechnique, Iowa State College Press, Ames, Iowa, 1951.

22. Scarth, G. W., Dehydration injury and resistance, Plant Phys. 16: 171-9, 1941.

23. - Cell physiology studies of frost resistance: A Review, New Phytol. 43: 1-12, 1944.

24. Shields, I. M., Leaf xeromorphy as related to physiological and structural influence, Bot. Rev. 16: 399-447, 1950.

25. - Leaf xeromorphy in dicotyledon species from a gypsum sand deposit, Amer. J. Bot. $38: 175-90,1951$.

26. Siminovitch, D., and Briggs, 1), R., Studies in the chemistry of the living bark of the black locust, in relation to its frost hardiness. III. The validity of plasmolysis and desiccation tests for determining the frost hardiness of bark tissue, Plant Phys. 28: 15-34, 1952.

27. Simpson, J. L. S., A short method of clearing plant tissues for anatomical studies, Slain T'ech. 4: 131-2, 1929.

28. Sites, J. W., Preconditioning of plants in relation to cold tolerance, Fla. Agr. Fxp. Sta. Ann, Rept., 1959. 
29. Smith, P. F., and Reuther, W., Seasonal changes in Valencia orange trees $I$. Changes in leaf dry weight, ash, and macro-mutrient olements, Proc. Amer. Soc. Hort. Sci. 56: $61-72,1950$.

30. Turrell, F. M., The area of interual exposed surface of dieotyledonous leuves, Amer. J. Bot. 23: 255 (44, 1936.

31. Webber, H. J., and Batchelor, I. D., The Citrus Industry, vol. I, Univ. Calif. Press, Berkeley, Calif., 1948.

32. Wiegand, K. M., The vecurrence of ice in plant tissue, Planl World 9: 25-39, 1906.

33. Young, R. H., and Peynado, A., Growth and cold hardiness of citrus and related species when exposed to different night temperatures, Proc. Amer. Soc. Hort. Sci 81: 238-43, 1962.

34. Ziegler, L. W., and Wolfe, IT. S., Citrus Crowing in Floridu, Univ. Mla. Press, Gainesville, Fla., 1961. 